\title{
18. PRELIMINARY STUDY OF TERRIGENOUS MINERALS: LIGHT AND HEAVY MINERALOGY OF SELECTED CORES, DEEP SEA DRILLING PROJECT, LEG 25
}

\author{
W. A. Girdley, Mesa College, Grand Junction, Colorado \\ and \\ Stan M. White, California State University, Fresno, California
}

\section{INTRODUCTION AND BACKGROUND}

Fifty samples of coarse sediments were selected from cores of five sites of Deep Sea Drilling Project, Leg 25, in the western and Southwestern Indian Ocean (Figure 1). Samples were studied to determine their light and heavy mineral compositions. The resulting information was used to determine possible source areas as well as to interpret, insofar as possible, characteristics of sedimentation and dispersal. This report should be considered as preliminary; additional work on the terrigenous sediments is in progress by the authors.

Ten samples each were selected from cores obtained at Sites 239, 240, 241, 246, and 248. A specific sampling program with reference to depths was not followed; therefore, the samples are from a variety of depths where coarse silt or sand units occur (Table 1). Most samples came from noticeable turbidite units within the cores; others were selected after the preliminary smear-slide examination showed a terrigenous-detrital mineral fraction.

\section{Procedures}

Samples were wet-sieved and only those fractions in the 125- to 63-micron-size (very fine sand) range were retained for this preliminary study. Minerals were separated into heavy and light fractions by settling through bromoform (specific gravity $=2.87$ ). Grain mounts and/or smear slides of the minerals were made from each sample by mounting in Caedex (refractive index $=1.576$ ). The heavy mineralogy was determined by identifying and counting 300 to 500 grains for each slide using a polarizing microscope with a mechanical stage. Identification of the light minerals is based on microscopic study of smear slides made from the light mineral separates. Some samples were stained and/or X-rayed to verify the microscopic identifications.

\section{Physiographic Settings and Lithologic Summaries}

Site 239, located in the western Mascarene Basin, is in a deep $(4971 \mathrm{~m})$ abyssal plain bordered by the steep eastern margin of the Madagascar Precambrian massif on the west and by the Mascarene Islands and Plateau on the east. The section penetrated consists of 320 meters of sediment of Pleistocene to Cretaceous (Maestrichtian) age. The samples were taken from the upper 140 meters of the cored section and represent three of the six lithologic units recognized. The three units are: Unit I, green and gray silty clay and clayey silt with light gray nannofossil ooze; Unit II, gray, light gray nannofossil ooze and nannofossil clay; and Unit III (similar to Unit I). The samples, in all cases, represent minor lithologies of the units and are from interbeds of silty clay or sandy silt. Grain-size analysis for the samples shows an everage of $33.7 \%$ sand. $54.6 \%$ silt, and $11.7 \%$ clay.

Site 240 (Holes 240 and 240A) is located in the central abyssal plain of the west Somali Basin about 350 miles west of the Seychelles and 500 miles east of Africa. The sediment section totaled 190 meters for Hole 240 and 200 meters for Hole 240A. The age of the sediment ranges from Holocene to early Eocene. Samples are from the 0-166 meter depth in Hole 240 and the 168-186 meter interval in Hole 240A. The samples of Hole 240 are from Unit I, which is predominantly gray to dark greenish-gray silty clay, clayey silt, and clay to silt-bearing nannofossil/ radiolarian ooze. For Hole $240 \mathrm{~A}$, the samples represent Unit II, which is a series of yellow to yellow-brown nannofossil ooze with interbedded sandy silt, silty clay, and sand. Six grain-size analyses correspond in depth to mineral

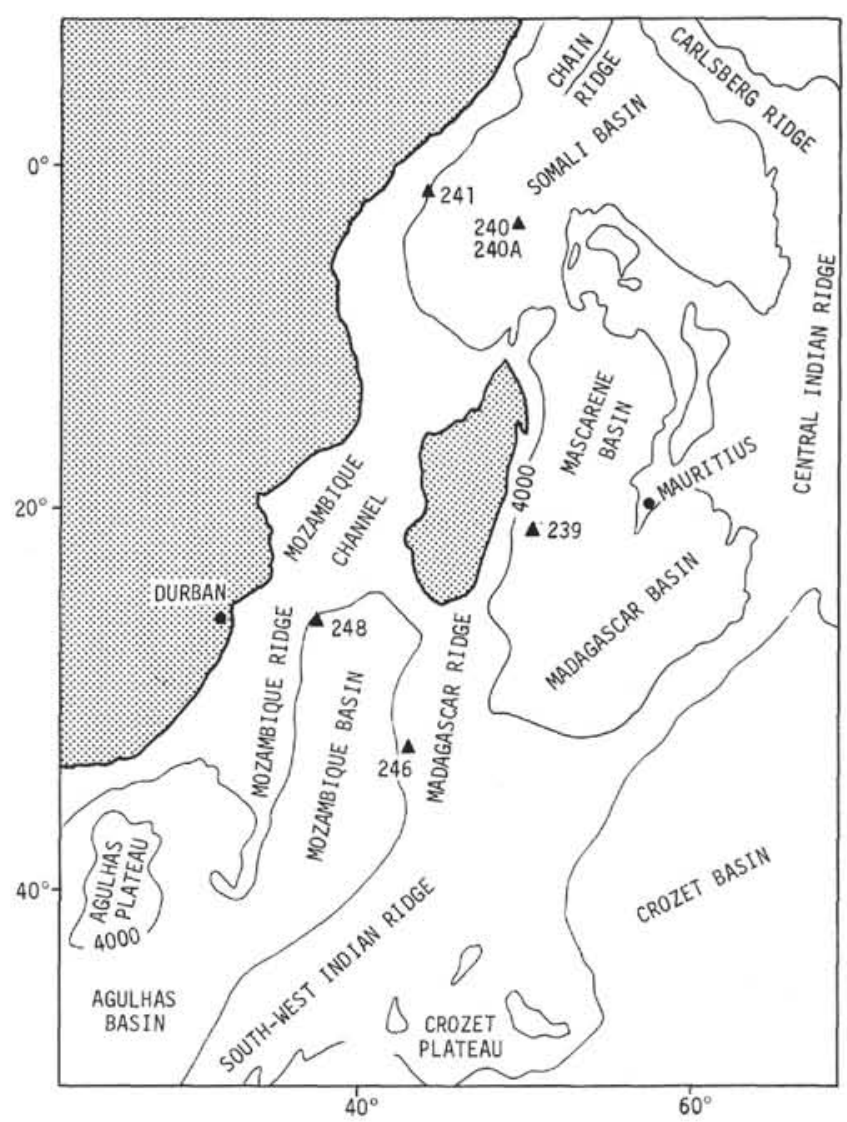

Figure 1. Site locations, light-heavy mineral studies. 
TABLE 1

Sample Numbers and Depths for Light and Heavy Mineral Studies

\begin{tabular}{|c|c|c|c|c|c|c|c|c|c|}
\hline \multicolumn{2}{|c|}{ Site 239} & \multicolumn{2}{|c|}{ Holes $240,240 \mathrm{~A}$} & \multicolumn{2}{|c|}{ Site 241} & \multicolumn{2}{|c|}{ Site 246} & \multicolumn{2}{|c|}{ Site 248} \\
\hline Sample & $\begin{array}{l}\text { Depth Below } \\
\text { Sea Floor }(\mathrm{m})\end{array}$ & Sample & $\begin{array}{l}\text { Depth Below } \\
\text { Sea Floor }(m)\end{array}$ & Sample & $\begin{array}{l}\text { Depth Below } \\
\text { Sea Floor }(m)\end{array}$ & Sample & $\begin{array}{l}\text { Depth Below } \\
\text { Sea Floor }(\mathrm{m})\end{array}$ & Sample & $\begin{array}{l}\text { Depth Below } \\
\text { Sea Floor }(\mathrm{m})\end{array}$ \\
\hline $1-1,92-94$ & $0-1$ & $1-1,74-76$ & $0-6$ & $3-3,101-103$ & $47-56$ & $5-1,90-92$ & $128-137$ & $2-3,50-52$ & $1-10$ \\
\hline $1-1,119-121$ & $0-1$ & $1-3,67-69$ & $0-6$ & $10-1,120-122$ & $218-221$ & $5-3,146-148$ & $128-137$ & $6-1,72-74$ & $151-160$ \\
\hline $1-1,129.5-$ & $0-1$ & $3-1,29-30$ & $73-82$ & $10-4,75-77$ & $218-221$ & $5-6,69-71$ & $128 \cdot 137$ & $6-1,132-134$ & $151-160$ \\
\hline & & $4-2,24-26$ & $148-157$ & $10-4,81-84$ & $218-221$ & $9-1,49-51$ & $164-173$ & $6, \mathrm{CC}$ & 160 \\
\hline $1, \mathrm{CC}$ & 9 & $4-2,69-71$ & $148-157$ & $10-4,87-90$ & $218-221$ & $9-3,72-74$ & $164-173$ & $7, \mathrm{CC}$ & $199-208$ \\
\hline $4-4,29-31$ & $66-75$ & $4-2,119-121$ & $148-157$ & $11-4,30-32$ & $256-265$ & $9 \cdot 6,29 \cdot 31$ & $164-173$ & $8-1,69-71$ & $227 \cdot 236$ \\
\hline $6-2,005-007$ & $84-93$ & $5-2,104-106$ & $157-166$ & $15-2,135-137$ & $398-401$ & $10-1,129-130$ & $176-185$ & $8, \mathrm{CC}$ & 236 \\
\hline $8-1,28-30$ & $131-140$ & $5-6,136-138$ & $157-166$ & $19-2,60-62$ & $530-539$ & $10-2,18-20$ & $176-185$ & $9-1,109-111$ & $265-274$ \\
\hline $8-4,103-104$ & $131-140$ & $1-1 \mathrm{~A}, 91-93$ & $168-177$ & $28-1,131-133$ & $1067-1072$ & $11-2,137-139$ & $185-194$ & $9-2,005-007$ & $265-274$ \\
\hline $8-5,23-25$ & $131-140$ & $2-1 \mathrm{~A}, 105-107$ & $177-1 \dot{8} 6$ & $28-2,71-73$ & $1067-1072$ & $11, \mathrm{CC}$ & 194 & $9, \mathrm{CC}$ & 274 \\
\hline $8-6,114-116$ & $131-140$ & & & & & & & & \\
\hline
\end{tabular}

samples for Holes 240 and 240A. For Hole 240, five samples have grain-size data. Three of these samples are classified as sands, with $66.1 \%$ to $97.1 \%$ sand. The remaining two samples are a silty clay with $8.8 \%$ sand and a silty sand with $65.5 \%$ sand. In Hole 240 A, the one sample has a grain-size analysis which shows sand-silt-clay percentages of $12.8,10.7$, and 76.5 , respectively.

Site 241 is located on the East African continental rise in the western part of the southern Somali Basin. The lithologic section penetrated totals 1174 meters of sediment and sedimentary rock of Middle Cretaceous (Turonian-Cenomanian) to Holocene age and consists of both shelf and deep-sea ooze, terrigenous-hemipelagic sediment, and turbidite. The samples of Hole 241 are from a wide range of depths $(47-1072 \mathrm{~m})$ in the cored section and are taken from three lithostratigraphic units which are: Unit I, nannofossil, foraminifer, diatom, and radiolarian oozes with greenish-gray silty clay, and clayey silt interbeds; Unit II, predominantly nannofossil ooze with silty clay, clayey silt interbeds; and Unit III, greenish-gray silty clay, claystone, clayey siltstone, sandstone, and minor nannofossil chalk.

Of the 10 mineral samples studied from Site 241,6 have grain-size analyses available at corresponding depths. Three of the samples are silty sand with sand percentages of 52.6 and 69.1 ; one is a sand-silt-clay with $36.4 \%$ sand $(27.7 \%$ is very fine sand); one is a clayey silt with $19.2 \%$ sand $(26 \%$ in the very fine sand mode); and, finally, one sample is a sand with $65.2 \%$ sand of which $9.6 \%$ is in the very fine sand range.

Site 246 is located slightly east of the Madagascar Ridge crest in a water depth of 1030 meters. A 194-meter sedimentary section was cored in which three lithologic units were recognized. The entire section ranges in age from Recent to early Eocene. The 10 samples span a depth range of 128 to 194 meters in the cored section and represent two lithostratigraphic units that are predominantly shelly and glauconite-rich/shelly calcareous sand. Three of the 10 mineral samples have corresponding grain-size data. Two of the samples are sand $(76.0 \%$ and $88.1 \%$ sand), while the third sample is a silty sand with $64.6 \%$ sand. One of the mineral samples taken (Core 5, Section 6) also has corresponding X-ray analysis data. The bulk X-ray analysis shows high values of calcite $(54.0 \%)$ and potash feldspar (43.4\%), with $2.7 \%$ quartz.

Site 248 is located in the Mozambique Basin. It is bounded on the eastern and western sides by steep linear scarps of the Madagascar and Mozambique ridges. Total penetration was 434 meters into Pleistocene ooze and silt, Pliocene to Miocene sand and clay, and Eocene to Paleocene clay. For Site 248, the 10 samples represent the upper 274 meters of the cored section and are from lithostratigraphic Unit I. This unit differs internally, based on the abundances of sand, silt, and nannofossils. The upper 40 meters contain equal amounts of sandy silt and silt and clay-rich nannofossil ooze. This is followed by 90 meters of silty clay and clayey silt and a final 56 meters of coarse-quartz sand and associated silty sand and clayeysandy silt. One grain-size analysis corresponds to a mineral sample (Core 2, Section 3). The sample is a silty clay with only $3.6 \%$ sand.

\section{MINERALOGY OF TERRIGENOUS SEDIMENTS}

\section{Light Mineralogy}

The light minerals from all five sites examined show remarkable similarity in that the dominant minerals consist of quartz and feldspar (Table 2). No exotic, precise source indicator minerals were found in the light mineral fraction. However, the generalization can be made that the light minerals are indicative of acidic plutonic or perhaps gneissic source rocks. The presence of considerable microcline in several samples suggests possible pegmatitic sources. The even extinction of a very significant amount of quartz argues against metamorphic sources, however. In addition, it was found that the terrigenous light mineral suite is similar throughout the length of any particular hole which suggests that the source for individual deposits in each hole remained the same with the passage of time.

\section{Results by Site}

Site 239, Mascarene Basin - The most notable terrigenous minerals are contained in silty clay and clayey 
TABLE 2

Light and Heavy Mineral Abundances by Site

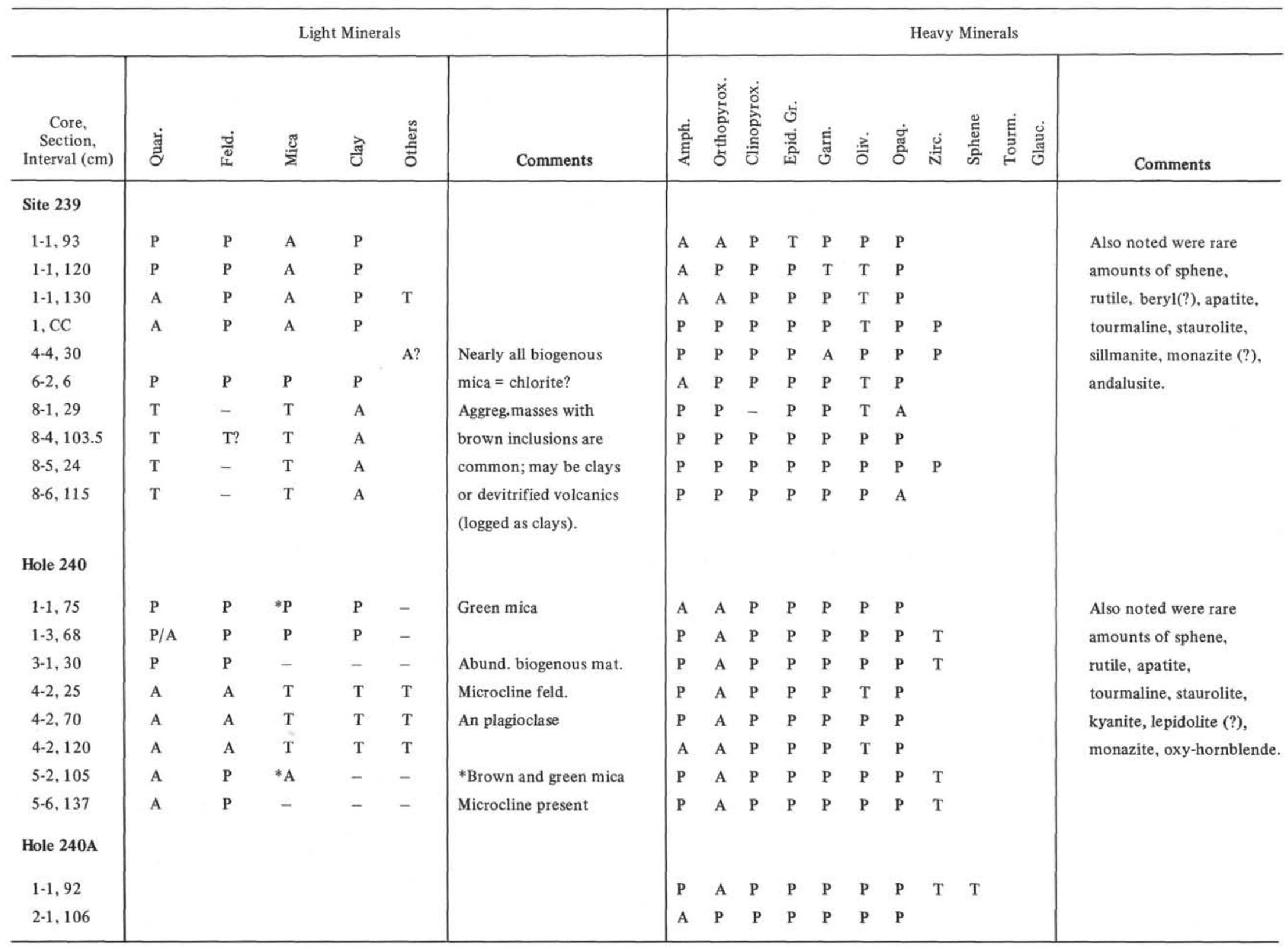




\begin{tabular}{|c|c|c|c|c|c|c|c|c|c|c|c|c|c|c|c|c|c|c|}
\hline \multicolumn{7}{|c|}{ Light Minerals } & \multicolumn{12}{|c|}{ Heavy Minerals } \\
\hline $\begin{array}{c}\text { Core, } \\
\text { Section, } \\
\text { Interval }(\mathrm{cm})\end{array}$ & 啹 & 竎 & $\frac{5}{2}$ & త্ & 总 & Comments & 趛 & 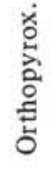 & 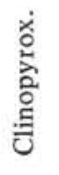 & $\begin{array}{l}\dot{0} \\
\text { 苛 }\end{array}$ & हुં & $\dot{z}$ & $\begin{array}{l}\dot{\widetilde{g}} \\
\text { ठ́ }\end{array}$ & : & 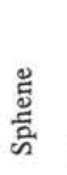 & 豆 & 迎 & Comments \\
\hline \multicolumn{19}{|l|}{ Site 241} \\
\hline $3-3,102$ & A & $\mathbf{P}$ & $\mathrm{T} / \mathrm{P}$ & $\mathrm{T}$ & & $\begin{array}{l}\text { Green chlorite: } \\
\text { microcline and plagioclase }\end{array}$ & A & A & $P$ & $P$ & $\mathbf{P}$ & - & $\mathbf{P}$ & & & & & \multirow{10}{*}{$\begin{array}{l}\text { Also noted were rare } \\
\text { amounts of rutile, } \\
\text { apatite, monazite, } \\
\text { staurolite, kyanite, } \\
\text { spinel, riebeckite (?), } \\
\text { oxy-hornblende. }\end{array}$} \\
\hline $10-1,121$ & A & A & $\mathrm{T}$ & $\mathrm{T}$ & & & A & A & P & $\mathbf{P}$ & P & - & P & & & & & \\
\hline $10-4,76$ & A & A & & & & Angular and rounded & A & A & $P$ & $P$ & $P$ & $\mathrm{~T}$ & $P$ & & & & & \\
\hline $10-4,83$ & A & A & & & & grains & A & A & $P$ & $\mathrm{~T}$ & $\mathbf{P}$ & - & $\mathrm{T}$ & & & & & \\
\hline $10-4,88$ & A & A & & & & & A & A & $P$ & $\mathbf{P}$ & $\mathbf{P}$ & $\mathrm{T}$ & $P$ & & & & & \\
\hline $11-4,31$ & A & A & & & & & A & $P$ & $P$ & $P$ & $P$ & $\mathrm{~T}$ & $\mathrm{P}$ & $\mathrm{T}$ & $\mathrm{T}$ & & & \\
\hline $15-2,136$ & A & $P$ & - & $P$ & & & $\mathrm{~T}$ & $P$ & $\mathbf{P}$ & $P$ & $\mathrm{P}$ & $\mathbf{P}$ & A & - & $\mathrm{T}$ & & & \\
\hline $19-2,61$ & $\mathrm{P}$ & $P$ & A & A & & & $\mathrm{T}$ & $\mathrm{P}$ & $\mathrm{P}$ & $\mathrm{T}$ & $\mathrm{P}$ & - & $P$ & & & & & \\
\hline $28-1,132$ & A & $P$ & $P$ & $P$ & ${ }^{*} \mathrm{~T}$ & *Volcanic clasts (?) & $P$ & $P$ & $\mathrm{~T}$ & $P$ & $P$ & $\mathbf{P}$ & A & $\mathrm{T}$ & $T$ & & & \\
\hline $28-2,72$ & A & $\mathbf{P}$ & - & $\mathrm{P}$ & & & $\mathrm{T}$ & $\mathbf{P}$ & $P$ & $P$ & $\mathbf{P}$ & $P$ & A & $\mathrm{T}$ & & & & \\
\hline \multicolumn{19}{|l|}{ Site 246} \\
\hline $5-1,91$ & $\mathrm{~T} / \mathrm{P}$ & $\mathbf{P}$ & $\mathrm{T}$ & & ${ }^{*} \mathrm{~T}$ & ${ }^{*}$ Micarb and glauconite & $\mathbf{P}$ & $\mathbf{P}$ & $\mathrm{T}$ & $P$ & - & - & A & - & & $\mathbf{P}$ & $P$ & \multirow{10}{*}{$\begin{array}{l}\text { Also noted were rare } \\
\text { Amounts of rutile, } \\
\text { beryl (?), sphene, } \\
\text { staurolite, sillimanite, } \\
\text { spinel (?), lepidolite (?) }\end{array}$} \\
\hline $5-3,147$ & $\mathrm{~T} / \mathrm{P}$ & $P$ & $\mathrm{~T}$ & & $T$ & & $P$ & $P$ & $\mathrm{~T}$ & $\mathrm{~T}$ & - & $\mathrm{T}$ & A & - & & $P$ & $\mathrm{P}$ & \\
\hline $5-6,70$ & $T / P$ & $\mathbf{P}$ & $\mathrm{T}$ & & $\mathrm{T}$ & & $P$ & P & $\mathrm{T}$ & - & $\mathrm{T}$ & - & A & - & & $\mathbf{P}$ & P & \\
\hline $9-1,50$ & $\mathrm{~T} / \mathrm{P}$ & $P$ & $\mathrm{~T}$ & & $\mathrm{~T}$ & & $\mathbf{P}$ & $\mathrm{P}$ & $\mathrm{T}$ & - & $\mathrm{T}$ & $\mathrm{T}$ & $\mathrm{P}$ & $\mathrm{T}$ & & $\mathbf{P}$ & A & \\
\hline $9-3,73$ & $\mathrm{~T} / \mathrm{P}$ & $P$ & $\mathrm{~T}$ & & $\mathrm{~T}$ & & $\mathbf{P}$ & $\mathrm{P}$ & $\mathrm{T}$ & $\mathrm{T}$ & $\mathrm{T}$ & - & A & - & & $\mathbf{P}$ & $\mathbf{P}$ & \\
\hline $9-6,30$ & $T / P$ & $\mathbf{P}$ & $\mathrm{T}$ & & $\mathrm{T}$ & & P & $P$ & - & $\mathrm{T}$ & - & $\mathrm{T}$ & A & - & & $\mathbf{P}$ & $\mathbf{P}$ & \\
\hline $10-1,130$ & $\mathrm{~T}$ & $\mathrm{P} / \mathrm{A}$ & & & ${ }^{*} \mathrm{P}$ & *Volcanic lithics & $\mathbf{P}$ & $\mathbf{P}$ & $\mathbf{P}$ & $P$ & $\mathrm{P}$ & $\mathrm{T}$ & A & - & & $\mathbf{P}$ & $\mathbf{P}$ & \\
\hline $10-2,19$ & $\mathrm{~T}$ & $\mathrm{P} / \mathrm{A}$ & & & $\mathrm{P}$ & & $\mathrm{T}$ & $\mathrm{P}$ & $P$ & $P$ & $\mathrm{P}$ & $\mathrm{T}$ & A & - & & $\mathbf{P}$ & $P$ & \\
\hline $11-2,138$ & $\mathrm{~T}$ & $\mathrm{P}$ & & & $* \mathrm{P}$ & ${ }^{*}$ Glauconite & $\mathbf{P}$ & $P$ & $\mathbf{P}$ & P & - & $\mathrm{T}$ & A & $\mathrm{T}$ & & A & $P$ & \\
\hline $11, \mathrm{CC}$ & $\mathrm{T}$ & P & & & ${ }^{*} \mathrm{P}$ & ${ }^{*}$ Glauconite & P & P & P & - & - & $\mathrm{T}$ & P & - & & P & $P$ & \\
\hline
\end{tabular}


Table 2 - Continued

\begin{tabular}{|c|c|c|c|c|c|c|c|c|c|c|c|c|c|c|c|c|c|}
\hline \multicolumn{7}{|c|}{ Light Minerals } & \multicolumn{11}{|c|}{ Heavy Minerals } \\
\hline $\begin{array}{c}\text { Core, } \\
\text { Section, } \\
\text { Interval }(\mathrm{cm})\end{array}$ & ةै & 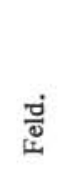 & 苞 & 졍 & 离 & Comments & 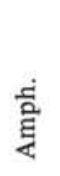 & 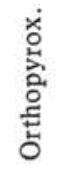 & 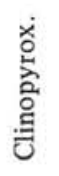 & 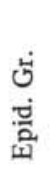 & હु & $\ddot{z}$ & 苂 & : & 䒕 & 豆 突 & Comments \\
\hline \multicolumn{18}{|l|}{ Site 248} \\
\hline $2-3,51$ & $\mathbf{P}$ & A & $\mathbf{P}$ & A & ${ }^{*} \mathrm{P}$ & *Volcanic lithics & $P$ & A & P & $P$ & $\mathrm{P}$ & $\mathrm{T}$ & $\mathbf{P}$ & - & & - & \multirow{10}{*}{$\begin{array}{l}\text { Also noted were rare } \\
\text { amounts of sphene, } \\
\text { rutile, glauconite, } \\
\text { apatite, monazite, } \\
\text { staurolite, lepidolite (?). }\end{array}$} \\
\hline $6-1,73$ & A & $P$ & $\mathrm{P}$ & - & ${ }^{*} \mathrm{~T}$ & ${ }^{*}$ Glauconite & A & $\mathrm{P}$ & $P$ & $P$ & $\mathrm{P}$ & $P$ & $\mathbf{P}$ & - & & $\mathrm{T}$ & \\
\hline $6-1,133$ & A & $\mathbf{P}$ & $\mathbf{P}$ & $P$ & ${ }^{*} \mathrm{~T}$ & & A & $P$ & $P$ & $P$ & $P$ & $\mathrm{~T}$ & $P$ & - & & - & \\
\hline $6, \mathrm{CC}$ & A & $\mathbf{P}$ & $\mathrm{P}$ & & ${ }^{*} \mathrm{~T}$ & & A & $\mathbf{P}$ & $\mathbf{P}$ & $P$ & $\mathrm{P}$ & $\mathbf{P}$ & $P$ & - & & $\mathrm{T}$ & \\
\hline $7, \mathrm{CC}$ & A & $\mathrm{P}$ & & & & & A & $P$ & $\mathrm{P}$ & $P$ & $P$ & $\mathrm{~T}$ & $\mathbf{P}$ & $\mathrm{T}$ & & $\mathrm{T}$ & \\
\hline $8-1,70$ & A & $\mathrm{P} / \mathrm{A}$ & & & ${ }^{*} \mathrm{~T}$ & $\begin{array}{l}{ }^{*} \text { Microcline and } \\
\text { plagioclase }\end{array}$ & A & $P$ & $\mathrm{P}$ & $P$ & $\mathrm{P}$ & - & $P$ & - & & - & \\
\hline $8, \mathrm{CC}$ & A & $\mathrm{P} / \mathrm{A}$ & & & ${ }^{*} \mathrm{~T}$ & $\begin{array}{l}{ }^{*} \text { Microcline and } \\
\text { plagioclase }\end{array}$ & A & $P$ & $\mathbf{P}$ & $\mathbf{P}$ & $\mathrm{P}$ & $\mathrm{T}$ & A & - & & - & \\
\hline $9-1,110$ & A & $\mathrm{P} / \mathrm{A}$ & $\mathrm{T}$ & $\mathbf{P}$ & ${ }^{*} \mathrm{~T}$ & & A & $\mathbf{P}$ & $\mathbf{P}$ & $\mathbf{P}$ & $P$ & $P$ & $\mathbf{P}$ & - & & - & \\
\hline $9-2,6$ & A & $\mathrm{P} / \mathrm{A}$ & $\mathrm{T}$ & $P$ & ${ }^{*} \mathrm{~T}$ & & $P$ & $\mathrm{P}$ & $\mathrm{T}$ & $\mathrm{T}$ & A & - & A & - & & - & \\
\hline 9, CC & A & $\mathrm{P} / \mathrm{A}$ & $\mathrm{T}$ & $P$ & ${ }^{*} \mathrm{~T}$ & & A & $P$ & $P$ & $P$ & $P$ & $\mathrm{~T}$ & A & - & & $\mathrm{T}$ & \\
\hline
\end{tabular}

Note: $\mathrm{T}=<1 \% ; \mathrm{P}=1-24 \% ; \mathrm{A}=>25 \%$. 
silt of Core 1. All samples show a nearly identical light mineral suite consisting primarily of quartz and feldspar with lesser amounts of green and olive-brown mica and clay. The quartz and feldspar are mostly angular and of a size near the lower limits of very fine sand. Quartz has rare inclusions and an even extinction. A few microcline grains are present. In Cores 4,6 , and 8 , the same mineral suite is found, but samples of these cores contain more micas and abundant aggregates of clay which may be devitrified volcanic derivatives.

Holes 240 and 240A, Somali Basin - Samples from Core 1 contain only a very small amount of definite terrigenous constitutents. These include quartz, potassiumfeldspar, clay minerals, and green mica. X-ray analysis reveals the presence of plagioclase, kaolinite, montmorillonite, and palygorskite. There are numerous inclusions in the quartz and feldspar and green mica contains black opaque inclusions. A few quartz grains exhibit a slight undulose extinction. Cores 4 and 5 contain detrital zones of sand and silty clay which have abundant terrigenous light minerals. Their mineral suites are nearly identical to each other and contain abundant quartz and feldspar. The latter consists of both potassium-feldspar and plagioclase. Microcline and albite-twinned plagioclase are both present in noticeable quantities. Plagioclase exhibits low extinction angles (less than $20^{\circ}$ ) which indicates sodic plagioclase. The mineral grains are mostly angular. Apatite inclusions occur in a few quartz grains, and inclusions are abundant in most quartz and feldspar grains. Brownish clay(?) aggregates are present throughout the samples.

Site 241, East African continental rise - Samples were studied from six cores at Site 241 which penetrated the thickest sediment section encountered on Leg 25 . The terrigenous suites are similar in all six cores. The samples of Core 3 were taken from a sand zone and contain abundant quartz, feldspar (including microcline), and plagioclase with excellent albite twinning. Inclusions occur in most grains. Abundant biogenous material, probably displaced from the shelf, is present. Core 10 contains silty sand which has the same terrigenous minerals as Core 3 . Many quartz grains contain black opaque inclusions. Both angular and rounded detrital grains are present indicating mixing of immature and mature sediments. The sample from Core 11, primarily a nannofossil ooze, contains minor amounts of the same terrigenous minerals reported for Core 10 . The sample from Core 15 has small amounts of terrigenous minerals which are identical to the more shallow zones, but there is less feldspar. Core 19 contains claystone and clayey siltstone with abundant clay minerals and mica and lesser amounts of quartz and feldspar. A few quartz grains exhibit undulose extinction. Core 28 consists partly of claystone which has abundant quartz with somewhat lesser amounts of feldspar, mica, and clay(?) aggregates. A few volcanic(?) rock fragments are present. The quartz and feldspar contain abundant inclusions and many grains seem to be corroded.

Site 246, Madagascar Ridge - Very little definite terrigenous sediment was found in samples from this hole. Although the samples examined are detrital, they are mostly biogenous in origin. The samples from Cores 5 and 9 contain, in addition to the detrital biogenous components, small amounts of quartz, potassium-feldspar, plagioclase, traces of mica, and reddish-brown grains which are identified as iron oxide-stained glauconite. All mineral grains are angular. Samples from Cores 10 and 11 (primarily silty clay zones) contain more feldspar than quartz with the feldspar exhibiting corroded and partially replaced rims. Volcanic rock fragments, especially grains of spherulitic material, are present. In addition, the samples of Core 11 contain considerable skeletal fragments which have been partially replaced by glauconite.

Site 248, Mozambique Basin - Although samples were analyzed from five cores in this hole, the terrigenous light mineral suites are remarkably similar. Samples of Core 2 consist primarily of what appear to be lumps of clay and volcanic rock fragments, especially fragments of spherulites. Numerous grains of brown and yellow mica are present. There is abundant feldspar, both potassium feldspar and plagioclase, with lesser amounts of quartz. Samples from Cores $6,7,8$, and 9 consist of nearly equal amounts of quartz and feldspar, lesser amounts of mica, traces of glauconite, and minor clay. The quartz grains include clear types, some with abundant black opaque inclusions, and a few with hematite staining. Numerous microcline grains are present as well as plagioclase which exhibits excellent albite twinning. The latter has low extinction angles indicating it is sodic plagioclase. Both angular and rounded grains occur indicating mixing of mature with immature sediments.

\section{Heavy Mineralogy}

The dominant heavy minerals for all but one site consist of the amphibole, ortho-and clinopyroxene, the epidote group, garnet, and opaques. The one exception is Site 246, where tourmaline is a major heavy mineral. A large variety of heavy minerals in rare or trace amounts were noted in the samples, and these are discussed for each individual site. Results of the heavy mineral determinations for all sites are also presented in Table 2 .

\section{Results by Site}

Site 239, Mascarene Basin - Only 4 of 10 samples can be considered as providing reliable data, as separations from the remaining samples were too poor to allow a count of at least 300 grains. Seven mineral groups dominate the heavy mineral fractions and include amphibole, orthopyroxene, clinopyroxene, epidote, garnet, olivine, and the opaques. Nine samples show amphibole $>$ orthopyroxene $>$ clinopyroxene with one sample indicating amphibole $>$ clinopyroxene $>$ orthopyroxene. Epidote has a higher percentage than garnet and clinopyroxene in five samples. Olivine generally averages approximately 1 to 2 percent but increases to 4 to 5 percent in samples from Core 8 . Biotite and chlorite are ubiquitous. Glauconite is present in sparse amounts. For the most part, the grains are fragmentary, subhedral, and exhibit very little abrasion, although some of the larger hornblende, epidote, and garnet are somewhat abraded. Solution etching was noted on some orthopyroxene and clinopyroxene. Other notable minerals include tourmaline (a purple, wine-colored variety); some exceptional euhedral zircons; a deep-blue pleochroic amphibole (riebeckite); sillimanite; a deep-red andalusite grain; sphene, staurolite, apatite, rutile, and possibly 
monazite and beryl. All of the above generally occur as single grains or in trace amounts.

Holes 240 and 240A, Somali Basin - Two of the 10 samples studied did not allow a 300-grain count. For the most part, grains are coarse or at the upper limit of 125 microns. Generally, samples shown orthopyroxene > amphibole $>$ clinopyroxene. However, two samples showed orthopyroxene $>$ clinopyroxene $>$ ampibole, and one sample of Hole 240A showed amphibole $>$ orthopyroxene $>$ clinopyroxene. Epidote, garnet, opaques, and olivine comprise the remaining four major mineral groups. Garnet is commonly of a higher percentage than epidote and both are more common than clinopyroxene in five samples. All grains tend to be subhedral and subrounded. This is especially true for garnet and epidote. Even some large zircons exhibit a rounded outline. The opaques are well rounded and a large number of opaque grains occur as abraded, stubby prisms, indicating that they may actually be thick hornblende grains. Isolated grains or trace amounts of the following minerals were also noted: sphene, zircon, rutile, apatite, tourmaline, staurolite, kyanite, monazite, oxyhornblende, and lepiodolite.

Site 241, East African continental rise - Five samples indicate orthopyroxene $>$ amphibole $>$ clinopyroxene, and three show amphibole $>$ orthopyroxene $>$ clinopyroxene. Two samples show insignificant amounts of amphibole, but orthopyroxene is more abundant than clinopyroxene. Garnet is more abundant than epidote and exceeds clinopyroxene in seven samples. Olivine, aside from the opaques, constitutes the seventh mineral group, although significant amounts of olivine (greater than 1\%) occurred only in those samples below Core 10 , Section 4 .

The mineral characteristics vary with all samples, but generally the rounding characteristics improve with increased grain size. Smaller sized grains $(63 \mu)$ are generally fragmentary, with rounding best developed on prismatic grains. Opaque minerals have a wide variety of shapes including prismatic shapes indicative of pyritized spicules. Some partially pyritized spicules were noted. Solution etching is present on some orthopyroxene. Other heavy minerals occurring as isolated grains or in trace amounts include: spinel (chromite?), riebeckite, oxyhornblende, sphene, zircon, rutile, apatite, monazite, tourmaline, staurolite, and kyanite. Core 12, Section 2 contains a notable amount of brown biotite and green chlorite.

Site 246, Madagascar Ridge - Counts of 300 grains were obtained for all samples examined. This site presents the most unique heavy mineral characteristics. First, the percentage of glauconite as distinct ovoid pellets ranges from 5.2 to 31.0. All cores obtained at this site are characterized as being glauconite-bearing or glauconite-rich. Secondly, tourmaline is ubiquitous, its presence exceeding the amphibole, orthopyroxene, or clinopyroxene. The varieties include buff, gray to smoky gray, purple, and green; shapes range from short stubby or slender euhedral prisms to rounded, abraded grains. Some minerals counted as opaques may really be thick tourmaline grains. Thirdly, yellow to light brown sillimanite is present in two samples from Core 10. Lastly, titaniferous augite (purple-red) is present with nearly all grains exhibiting an excellent etched "cockscomb" structure. Solution etching was noted on the orthopyroxenes, also. Other minerals present include epidote, garnet, and olivine. Epidote content is generally less than garnet except for four samples, and garnet is uncommon in five samples; it averages 1 percent for three samples, and for two samples $(10-1,10-2)$ it constitutes a high percentage $(>3 \%<8 \%)$. Trace amounts or single grains of sphene, zircon, rutile, staurolite, spinel, monazite, and beryl(?) were also noted.

Site 248, Mozambique Basin - The heavy minerals from Site 248 are unique in that they all are coarse grained, representing sizes close to 125 microns. Nine of 10 samples show amphibole $>$ orthopyroxene $>$ clinopyroxene, with a single sample showing orthopyroxene $>$ amphibole. Epidote, olivine, and garnet are ubiquitous. Zircon, sphene, rutile, glauconite, apatite, tourmaline, and staurolite occur in trace amounts or as rare single grains.

Most minerals show a rounded or abraded form with this characteristic most noticeable on the more equidimensional grains. Some orthopyroxene and clinopyroxene show well-developed solution etching.

\section{PROVENANCE GEOLOGY}

Because of the geologically diverse and widely separated nature of the five sites, it follows that provenances for the terrigenous minerals also differ significantly. Probable provenance areas, based on proximity and physiographic conditions necessary for sediment transport for each of the five sites, may be generally designated as follows:

Site 239 (Mascarene Basin) - Terrigenous contributions are possible from eastern Madagascar and from the Mascarene Islands.

Holes 240, 240A (Somali Basin) - Eastern Africa (Somalia and Kenya) and the Seychelle Islands could provide terrigenous sediment.

Site 241 (East African continental rise) - Terrigenous sediment could be derived primarily from eastern Africa (Somalia, Kenya, and Tanzania) and from western Madagascar.

Site 246 (Madagascar Ridge) - The majority of terrigenous detritus would appear to have come from southern Madagascar or from portions of the Madagascar Ridge.

Site 248 (Mozambique Basin) - Terrigenous debris could be derived from eastern and southeastern Africa (Mozambique and South Africa) as well as from western and southwestern Madagascar.

The nature of the provenances was not determined first-hand by the authors. The basis for the following petrologic and mineralogic descriptions is a review of the available literature and is therefore not intended to be all-encompassing.

\section{Mascarene Islands}

Réunion, Mauritius, and Rodriquez are three volcanic islands in this group. Rock types include basaltic flows (mainly dolerites), labradorite basalts, oceanites, phonolitic trachytes, and andesites. Both Fisher et al. (1967) and Hekinian (1968) report that pyroclastics in abyssal plain sediments, derived from Réunion and Mauritius, contain olivine (forsterite) and pyroxene. Upton et al. (1967) and Upton and Wadsworth (1966) in a more detailed 
mineralogical study of the Rodriquez and Réunion basalts reported olivine (fosterite), hypersthene, brown hornblende, clinopyroxenes (including pale augite and titanaugite), as well as apatite and spinel. Simpson (1950) also reported a basalt mineralogy for Mauritius which included olivine, clinopyroxene, and orthopyroxene.

\section{Seychelles}

The larger islands of the Seychelles group are granitic, while smaller islands consist of coral sand. The granitic rocks (syenite and microgranite) contain olivine-bearing basaltic dikes and sills as well as andalusite-bearing hornfels roof pendants.

\section{Madagascar}

\section{Eastern Region}

Nearly all of the eastern part of Madagascar is composed of Precambrian crystalline igneous and metamorphic rocks with a thin belt of Cretaceous volcanic and sedimentary rocks occurring along the coast.

The crystalline basement rocks include: the Androyen sequence consisting of quartz-feldspar gneiss, quartzite, crystalline limestone, and a charnockite facies (a dry granite characterized by hypersthene); the Graphite system consisting of anorthosite, gneiss, mica schist, and beds of graphite (also included is the Brichaville granitoid migmatite, with large garnet, amphibole, and associated charnockite); the Vohibory system which contains sericite, chlorite and talc schist, greenschist, gneiss, amphibolite, epidotite, and leptynite; the Crystalline Limestone or Marbles system is composed of shale, quartzite, mica schist, and dolomitic and siliceous marble; and the Schist and Quartzite, or Quartzite series, consisting of quartzite with basal shales that are weakly metamorphosed and of granitic intrusions containing beryl and columbotantalite.

Haughton (1963) notes the following distinctive mineralogy for Precambrian units in Madagascar:

$$
\text { Unit Indicator Minerals }
$$

Ft. Dauphin

Tranomaro

Andriba

Vohibory

Ambodiriana

Ampanihy

Quartzite

(Andringitran Granite)

Clifford and Gass (1970) also provide some detailed insight as to distinctive mineralogy in Precambrian units on
Madagascar. The Tsaratanama group in the northern areas contains xenotime, monazite, beryl, columbite, allanite, and zircon; the Andriamen-Ankazobe group contains monazite, beryl, and columbite; the Sahatany Group contains beryl, topaz, and notable tourmaline; and the Ampandram-Ania-Malakialina group contains notable beryl, columbite, black tourmaline, and zircon.

The Cretaceous sequence of Madagascar is apparently of Late Cretaceous age and consists of both volcanics and sediments. Little information is available concerning this sequence except an indication that the basalts belong to the Sakalanite group, having large augite crystals and rare olivine. Haughton (1963) reports that Mesozoic rocks in the northwest contain hornblende, riebeckite, and apatite.

\section{Western Region}

The western area consists of a belt of sedimentary rocks which onlap the crystalline basement to the east and which range in age from late Carboniferous to Tertiary. Rock units vary in their sedimentary composition and are described in some detail by Furon (1963) and by Dixey (1960); however, neither author notes any unit with a distinctive mineralogy.

\section{East Africa}

Because of the areal size and diversity of rock units in this provenance area, the following discussion is specific only where significant characteristics are worth noting in terms of sediment contribution to the sites. Dixey (1960) provided a comparison of the geology of Madagascar with eastern Africa. He noted that: (1) the metamorphic region of both areas is similar, although the metamorphic grade is higher in eastern Africa; (2) the crystalline basement rocks are difficult to compare between the two areas; and (3) late Paleozoic, Mesozoic, and Tertiary sediments are comparable in many respects, as are volcanic deposits of Tertiary and post-Tertiary age.

Haughton (1963, 1969); Clifford and Gass (1970); and Cahen and Snelling (1966) have all published extensively on African geology. It is beyond the scope of this preliminary report, however, to consider all possible source areas or all possible drainage systems which could conceivably contribute to the mineralogy of the sediments. It is safe to say, however, that contributions from East Africa could include the following diagnostic minerals: garnet (red, Mg-rich), rutile, zircon, tourmaline, staurolite, apatite, sphene, olivine, hypersthene, xenotime, enstatite, riebeckite, clinopyroxene, kyanite, corundum, monazite, epidote, allanite, beryl, and amphibole.

Dr. J. von Stackleberg of the Bundesanstalt Für Bodenforschung made several heavy mineral studies of sediments cored from the continental shelf and slope between Beira and Ilha, Mozambique. He reports (1973, personal communication) that the following heavy minerals (5.6-2.96) are distinctive in the samples: green amphiboles, pyroxene (mainly clinopyroxene), epidote (mainly pistasite), garnet (almandine rich), kyanite, staurolite, sillimanite, apatite, tourmaline, zircon, and opaques, including ilmenite, rutile, hematite, and rare magnetite. Stackleberg feels that the majority of the minerals are derived from metamorphics of the crystalline basement of the hinterland 
with minor contributions from pegmatite sources. For his sample groups, the Zambesi River was the chief source.

\section{SUMMARY AND CONCLUSIONS}

The diversified light and heavy mineral content of the samples, combined with a variety of site locations and possible provenances for each site, does not allow highly precise conclusions to be reached at this time. Therefore, only tentative interpretations concerning source areas and dispersal histories have been attempted.

\section{Site 239, Mascarene Basin}

Clear quartz, its even extinction, and the presence of microcline are indicative of plutonic (perhaps pegmatitic) source rocks. These sources could also supply the major heavy minerals reported (amphibole, orthopyroxene, and clinopyroxene) as well as rarer tourmaline and zircon. Contributions from metamorphic sources are indicated by garnet and rare amounts of staurolite, riebeckite(?), andalusite, and sillimanite. Volcanic contributions are indicated by the presence of a possible devitrified volcanic clay plus olivine grains.

Terrigenous contributions from the crystalline complexes of eastern Madagascar seem viable here, with a strong possibility of volcanic contributions from the Mascarene Islands via turbidity currents or air-fall mechanisms (Goldberg and Griffin, 1970). Haughton (1963) noted many of the trace heavy minerals reported for Site 239 as occurring in rocks of eastern Madagascar.

\section{Hole 240-240A, Somali Basin}

Terrigenous sediments of Holes 240 and 240A seem to indicate the source to be eastern Africa, along with distal contributions from the Seychelles. The majority of the light fraction suggests plutonic acidic source rocks. Minor amounts of undulatory quartz is suggestive of a partly metamorphic source. The heavy mineral suite is of itself not distinctive of a particular source but is in agreement with those cited above. The coarse-grained (upper limit of very fine sand) nature of the heavy minerals plus their abraded nature seem indicative of short distance, rapid, turbulentabrasive transport which could be caused by turbidity currents crossing the East African continental slope.

\section{Site 241, East African Continental Rise}

Proximity of this hole to the East African and western Madagascar crystalline complexes is noteworthy. The light mineral suite indicates that source rocks probably include acidic plutonic or partially pegmatitic igneous rocks, gneissic metamorphics, and volcanics. The heavy mineral suite lends support to these possibilities. The quartz and the heavy minerals in the sediments exhibit both rounded and angular forms, which probably indicates mixing of first and second cycle sediments. The East African and western
Madagascar areas contain extensive sedimentary covers above the crystalline complexes which could provide grains that have experienced at least one previous cycle of transport.

\section{Site 246, Madagascar Ridge}

The light minerals and lithic fragments are indicative of crystalline complexes and volcanic terranes. Significant heavy minerals present include tourmaline, sillimanite, and titaniferous augite. The proximity of the Madagascar Ridge to southern Madagascar suggests the latter to be the probable sediment source, and the heavy minerals found are the same as those reported to be present in the crystalline complexes of Madagascar by Haughton (1963) and Clifford and Gass (1970).

\section{Hole 248, Mozambique Basin}

Source rocks include acidic plutonics, pegmatites, and volcanics as indicated by light minerals and lithic fragments. Extensive glauconite in both the light and heavy mineral fractions suggests derivation from East Africa or from the Madagascar Ridge or both. The heavy minerals are coarse, abraded, and contain ubiquitous epidote, garnet, and olivine. Rare tourmaline also occurs.

\section{REFERENCES}

Cahen, L. and Snelling, H. S., 1966. The geochronology of equatorial Africa: Amsterdam (North Holland Publishing Co.).

Clifford, T. N. and Gass, I. G. (Eds.), 1970. African magmatism and tectonics: Edinburgh (Oliver and Boyd).

Dixey, F., 1960. The geology and geomorphology of Madagascar and a comparison with eastern Africa: Geol. Soc. London Quart. J., v. 116, p. 255-268.

Fisher, R. L., Johnson, G. L., and Heezen, B. C., 1967. Mascarene Plateau, western Indian Ocean: Geol. Soc. Am. Bull., v. 78, p. 1247-1266.

Furon, R., 1963. Geology of Africa: New York (Hafner Publishing Co.).

Goldberg, E. D. and Griffin, J. J., 1970. The sediments of the northern Indian Ocean: Deep-Sea Res., v. 17, p. 513-537.

Haughton, S. H., 1963. Stratigraphic history of Africa south of the Sahara: London (Oliver and Boyd). 1969. Geologic history of southern Africa: Capetown (Geol. Soc. South Africa).

Hekinin, R., 1968. Rocks from the mid-ocean ridge in the Indian Ocean: Deep-Sea Res., v. 15, p. 195-213.

Simpson, E. S. W., 1950. The geology and mineral resources of Mauritius: Colonial Geol. Min. Res., v. 1, p. 217-241.

Upton, B. G. J. and Wadsworth, W. J., 1966. The basalts of Reunion Island, Indian Ocean: Bull. Volcanologique, v. 29 , p. $7-24$.

Upton, B. G. J., Wadsworth, W. J., and Newman, T. C., 1967. The petrology of Rodriquez Island, Indian Ocean: Geol. Soc. Am. Bull., v. 75, p. 1495-1506. 